\title{
Stratifying, partially redrying, and storing Douglas-fir seeds : biochemical responses *
}

\author{
Marlene DE MATOS MALAVASI, Te May CHING and D.P. LAVENDER \\ Department of Forest Science, \\ Oregon State University, Corvallis, OR 97331, U.S.A.
}

\begin{abstract}
Summary
Certain biochemical attributes (adenosine phosphates, nucleic acids and total nucleotides) were analyzed in Douglas-fir [Pseudotsuga menziesii (Mirb.) Franco] seeds and seedlings from a coastal and an interior seed source in Oregon to explore how seed stratification, redrying and storage interact to produce vigorous secdlings. Seeds were stratified at 45 p. 100 moisture content (MC) and then redried (to 35 or $25 \mathrm{p} .100 \mathrm{MC}$ ) and/or stored (for 1 or 3 months) in a range of treatment combinations. Stratification increased ATP 13 -fold in the embryo and 6-fold in the gametophyte; energy charge rose from 0.4 to 0.8 , and RNA increased 60 to $80 \mathrm{p}, 100$ in the embryo and 150 to $300 \mathrm{p} .100$ in the gametophyte. Redrying stratified seeds to 35 or 25 p. $100 \mathrm{MC}$ increased RNA and DNA greatly in the embryo but not in the gametophyte. Storing redried seeds generally reduced all biochemical attributes. Stratified, redried seeds produced the most vigorous seedlings, though their biochemical attributes showed no constant advantage, possibly due to their rapid metabolism. However, the bencfit of stratification and redrying was not preserved in stored seeds of either source.
\end{abstract}

Key words : Douglas fir, seed variability, germinability, dormancy, vigor, adenylate pool, nucleic acids, nucleotides, protein synthesis.

\section{Introduction}

Stratification treatment (moist chilling) is a commonly used technique for overcoming dormancy in seeds of many temperate-zone species, including broadleaved trees, e.g., oak (Quercus spp.; SUszKA \& TYlKowskı, 1981) and beech (Fagus spp.; Muller \& BonNet-Masimbert, 1983). However, practical problems arise in synchronizing the end of stratification with the desired sowing date and in preserving surplus stratified seeds beyond the optimum stratification period without incurring seed loss from pregermination or deterioration.

Some workers have found that stratified seeds of Douglas-fir |Pseudotsuga menziesii (Mirb.) Franco] (Vanesse, 1967 ; Hedderwick, 1968) and loblolly pine U.S.A.

* F.R.L. 1903, Forest Research Laboratory, Oregon State University, Corvallis, OR 97331, 
(Pinus taeda L.) (BARNetT, 1972) may be redried and stored at low temperature without losing viability, though the stratification effect was lost. SuszKa (1975) observed that dormancy-broken beech nuts, at 28 p. 100 moisture content and stratified at 3 " $\mathrm{C}$ for about 3 months, can be rapidly dried at 15 to 20 " $\mathrm{C}$ to $10 \mathrm{p} .100$ moisture content and stored at $-10^{\circ} \mathrm{C}$ in sealed containers, and their viability and germinability preserved for $3 \frac{1}{2}$ months. DANIELSON \& TANAKA (1978) reported that stratified ponderosa pine (Pinus ponderosa Dougl. ex Laws.) seeds redried to approximately 26 p. 100 moisture content were stored for 9 months without losing their viability or stratification benefits, though germination of Douglas-fir secds was reduced about 40 p. 100 , probably due to their higher moisture content (approximately 37 p. 100) during storage. More recently, EDwards (1981) found that stratified Abies seeds redried to approximately 25 p. 100 moisture content could be successfully stored for 12 months without losing their viability or the stratification effect and, further, that redrying stratified seeds stimulated germination to much higher levels than stratification alone. Indeed, we show in the companion paper (DE Matos MalavasI et al., 1985) that redrying Douglas-fir seeds to 35 and 25 p. 100 moisture content produced heavicr, larger, and more vigorous seedlings than stratification alone.

We conducted the research reported here and in the companion paper just noted to study further the physiological effects of stratification on Douglas-fir seeds and the possible expression of those effects during germination. Although some work has been done on the physiology of redrying stratified seeds, there is little information about metabolic changes occurring during the process. When the breaking of seed dormancy has been stimulated by processes such as stratification, the synthesis of nucleotides and nucleic acids may be enhanced (WOOD \& BradBEER, 1967; JARVIS et al., 1968 a, b; Khan et al., 1968 ; Villifers, 1972; Tao \& Kilan, 1974; Davies \& Pinfield, 1979) and energy status elevated (ChING \& Ching, 1972, 1973 ; SzczotKa \& Tomaszewska, 1980; Murphy \& Noland, 1982). In this aspect of the study, we investigated whether some of the known biochemical effects of stratification - specifically, quantitative changes in adenosine phosphates, total nucleotides, and nucleic acids - occur during redrying and storage and whether these effects are manifested in germinated seedlings.

\section{Materials and methods}

Two Douglas-fir seed lots with high germinative capacity were obiained from a commercial seed company. Seeds in both lots were collected in 1980 in Oregon, one lot from coastal seed zone 061 (elevation $0-152 \mathrm{~m}$ ), the other from interior seed zone 252 (elevation 153-305 m). Seeds were stored for 4 months in airtight containers at 1 "C, then, before experimentation, screened to obtain large, uniform size. Screened seeds of both lots [average moisture content (MC) of 7 p. 100] were stored at 1 "C over the 2-year duration of the experiment.

\subsection{General procedure}

Seeds were soaked in water at room temperature for 24 hours, drained, placed in 4-mil polyethylene bags, and then stratified at $3{ }^{\circ} \mathrm{C}$ for 28 days at $45 \mathrm{p} .100 \mathrm{MC}$. 
MC of some stratified seeds was adjusted downward to 35 or 25 p. 100 by redrying seeds in a single layer on a mesh screen inside a standard room ( 21 "C temperature, 70 p. 100 relative humidity) for 20 minutes or 48 hours, respectively ; the method for determining the target MC levels is detailed in the companion paper (Dr: MAtos MaLAVASI et al., 1985). Most redried ( 35 or 25 p. $100 \mathrm{MC}$ ) and nondried (45 p. $100 \mathrm{MC}$ ) seeds were then placed in dry 4 -mil polyethylene bags and returned to cold storage ( 3 "C) for 1 or 3 months; the rest were not stored. In total, seeds from the original sample (7 p. $100 \mathrm{MC})$ and seeds at three MCs $(45,35$, and 25), stored for two periods (1 and 3 months) or not stored at all, composed the 10 treatments (tabl. 1). Within each treatment, whole seeds, seed parts (gametophyte and embryo), and 5-day-old seedlings were assayed for adenosine phosphates, nucleotides, and nucleic acids. Impacts of redrying and storage on growth responses (expressed as seed germination and vigor, seedling length and dry weight) are discussed in the companion paper.

\section{TABLE I}

Treatment descriptions and corresponding experimental coles for Douglas-fir seed from the two seed lots studied.

Description des traitements et codification utilisée pour les deux lots de graines de Douglas étudiés.

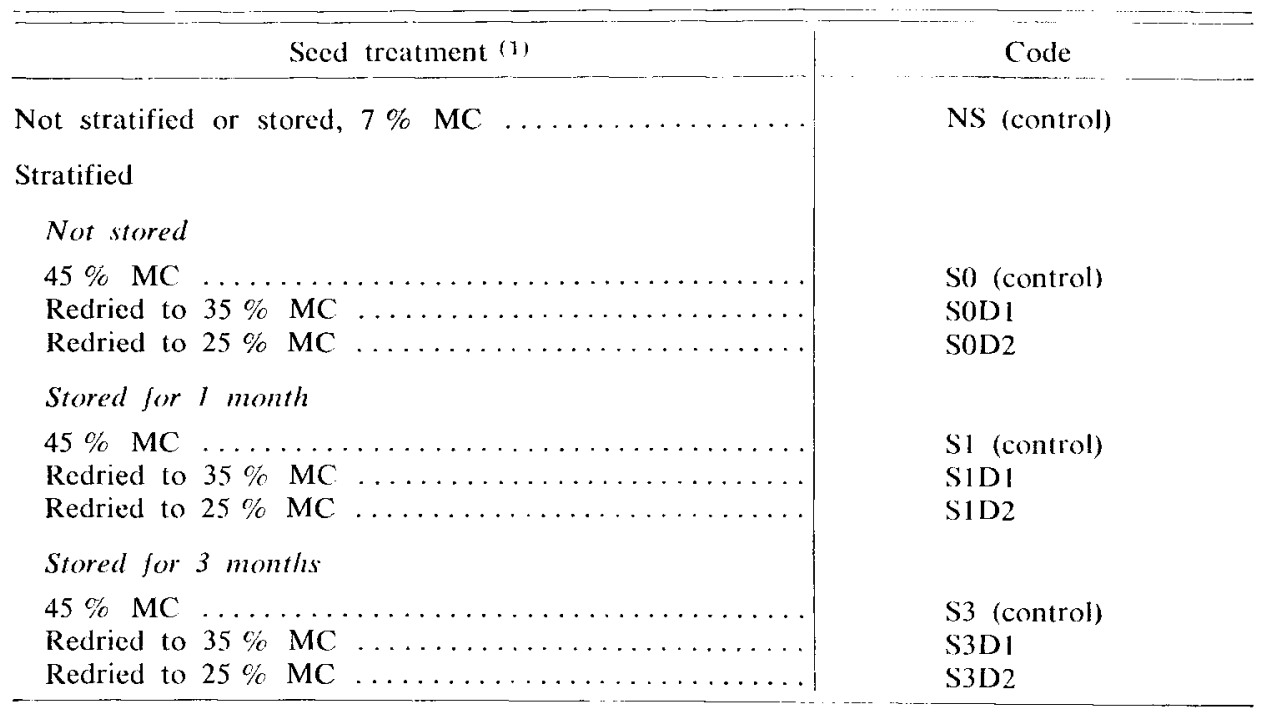

(1) $\mathrm{MC}=$ moisture content.

Four hundred treated seeds (four replications of 100 seeds each) were germinated in clear, covered plastic dishes containing $200 \mathrm{ml}$ of sterilized peat moss and vermiculite and $15 \mathrm{ml}$ of water. Temperature alternated daily between $30^{\circ} \mathrm{C}$ for 8 hours and $20^{\circ} \mathrm{C}$ for 16 hours; illumination with cool-white fluorescent lights (1000 lux) 
accompanied the higher temperature period. Seeds were considered germinated when their radicles were at least $2 \mathrm{~mm}$ long. Germinants were counted every second day, up to 28 days.

\subsection{Extracting adenosine phosphates, nucleotides, and nucleic acids}

Sixty seeds (three replications of 20 seeds each, for all storage periods and MCs) were dissected into seed coat, gametophyte, and embryo. Dissection to embryos and gametophytes was on chilled moist filter paper for stratified seeds, on dry filter paper for nonstratified (NS) seeds. Adenosine phosphates, nucleotides, and nucleic acids were then extracted from these embryos and gametophytes on day 0 of germination and from 12 seedlings (three replications of four seedlings each) 5 days after radicles had emerged.

Embryos, gametophytes, and seedlings were first ground with $0.25 \mathrm{M}$ perchloric acid (Ching et al., 1974). The slurry extract was centrifuged at $10 \mathrm{~kg}$ for 10 minutes and the precipitate stored for nucleic-acid analysis. The supernatant was neutralized with $2 \mathrm{~N}$ KOH and $0.1 \mathrm{M} \mathrm{N}$-2-hydroxyethyl piperazine- $\mathrm{N}^{\prime}$-2-ethanesulfonic acid (HEPES) buffer, $\mathrm{pH} 7.0$, and titrated with $\mathrm{KOH}$ to $\mathrm{pH} 7 \pm 0.1$. The neutralized extract was centrifuged at $10 \mathrm{~kg}$ for 5 minutes and the precipitate removed. An aliquot of the neutralized extract was used for adenosine phosphate assay and the remaining extract for nucleotide estimation.

\subsection{Lstimating adenosine phosphate levels and adenylate energy charge}

Adenosine phosphate levels were estimated by the luciferin-luciferase method with an Aminco Chem-Glow photometer (CHING \& CHING, 1972). Freeze-dried firefly extract containing luciferin-luciferase was purchased from the Sigma Chemical Co., St. Louis, Mo. (FLE-50). The neutralized extract was properly diluted to the instrument sensitivity with $0.025 \mathrm{M}$ HEPES buffer containing $0.025 \mathrm{M} \mathrm{Mg}$ acetate, $\mathrm{pH} 7.5$. Adenosine triphosphate (ATP) was determined in the diluted extract directly. Adenosine diphosphate (ADP) was converted to ATP by phosphoenol-pyruvate and pyruvate kinase (EC 2.7.1.40) and then assayed. Adenosine monophosphate (AMP) was converted to ADP with endogenous ATP by adenylate kinase (EC 2.7.4.3), and the resulting ADP converted to ATP and assayed. A standard curve relating photometer readings produced when standard quantities of authentic ATP were reacted with the firefly extract was used as a basis for converting the photometer readings of experimental extracts to levels of ATP. Adenylate energy charge (EC) was calculated according to ATKINSON (1969):

$$
E C=\frac{(A T P)+\frac{1}{2}(A D P)}{(A T P)+(A D P)+(A M P)}
$$

\subsection{Estimating acid-soluble nucleotides and nucleic acids}

Nucleotides in the neutralized extract were separated by ion-exchange chromatography with a Dowex 1-x8 resin, 50-100 mesh column, and estimated from the $A_{260}$ of the ammonium formate eluate (CHING, 1966). 
Ribonucleic acid (RNA) and deoxyribonucleic acid (DNA) were assayed by the diphenylamine and orcinol procedure in the $\mathrm{HClO}_{4}$-extracted residue (CHING, 1966). Highly purified yeast RNA and highly polymerized calf thymus DNA (all from Sigma) were subjected to the procedures and used as standards for quantitative estimation.

\subsection{Statistical analysis}

Initially, analysis of variance for a completely randomized design was conducted on all data to assess significant treatment effects. Then t-tests were used to determine which treatment means were significantly different at the 5 p. 100 probability level $(\mathrm{P}<0.05)$.

\section{Results and discussion}

For both seed sources, amounts (mean \pm standard deviation) of the various biochemical attributes in embryos, gametophytes, and 5-day-old seedlings are summarized in figures 1 (coastal) and 2 (interior). Changes in EC are presented in table 2, statistical comparisons in table 3 .

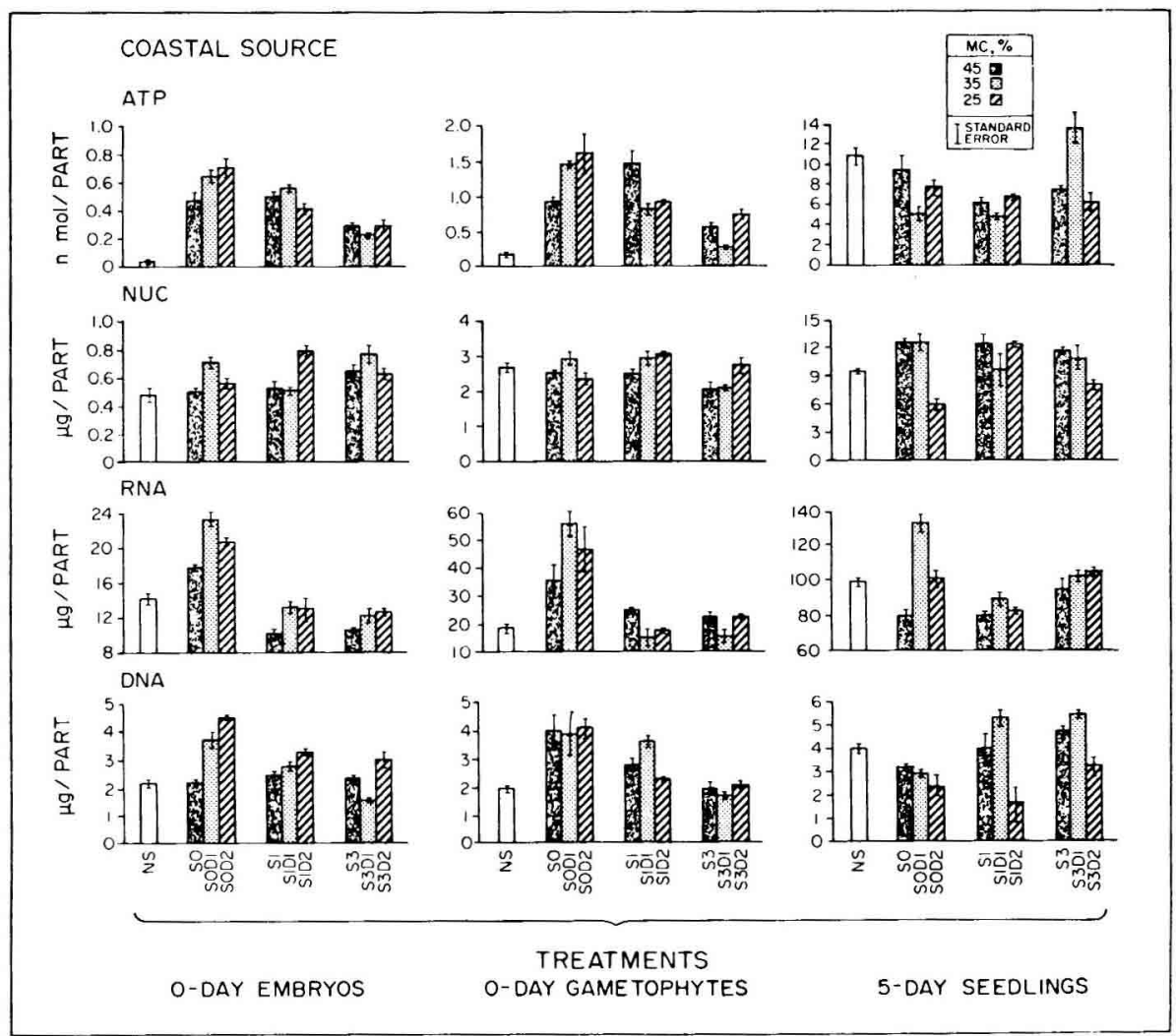

FIG. 1

Effects of redrying and storage on ATP, total nucleotides (NUC), RNA, and DNA contents in 0-day embryos and gametophytes of variously treated Douglas-fir seeds and their 5-day germinants for the coastal seed source.

See table 1 for treatment-code explanations. 


\section{TABLE 2}

Changes in adenylate energy charge (1) in Douglas-fir seeds and 5-day-old seedlings from both seed sources.

Changements dans la charge énergétique (adénylique) dans les graines de Douglas provenant de deux sources de graines et leurs semis après 5 jours.

Treatment (2)

0-day seeds

\begin{tabular}{|c|c|c|c|c|}
\hline & Embryo & Gametophyte & Embryo & Gametophyte \\
\hline NS & 0.37 & 0.31 & 0.51 & 0.54 \\
\hline so & 0.87 & 0.76 & 0.86 & 0.77 \\
\hline$\$ 1$ & 0.70 & 0.70 & 0.78 & 0.75 \\
\hline S3. & 0.68 & 0.82 & 0.81 & 0.58 \\
\hline SOD1 & 0.60 & 0.81 & 0.79 & 0.71 \\
\hline$S 1 D 1 \ldots \ldots \ldots$ & 0.78 & 0.75 & 0.86 & 0.74 \\
\hline S3D1 ... & 0.76 & 0.66 & 0.79 & 0.73 \\
\hline SOD2 $\ldots$ & 0.59 & 0.88 & 0.75 & 0.44 \\
\hline $\mathrm{S} 1 \mathrm{D} 2 \ldots$ & 0.88 & 0.71 & 0.79 & 0.72 \\
\hline S3D2 & 0.66 & 0.69 & 0.59 & 0.75 \\
\hline
\end{tabular}

5-day germinants

\begin{tabular}{|c|c|c|c|c|}
\hline & Seedling & Gametophyte & Seedling & Gametophyte \\
\hline NS $\ldots \ldots \ldots \ldots \ldots$ & 0.67 & 0.89 & 0.84 & 0.80 \\
\hline so ... & 0.86 & 0.81 & 0.76 & 0.79 \\
\hline$S I \ldots \ldots$ & 0.72 & 0.74 & 0.80 & 0.75 \\
\hline$\$ 3 . \ldots$ & 0.86 & 0.76 & 0.80 & 0.90 \\
\hline SOD $1 \ldots$ & 0.68 & 0.70 & 0.79 & 0.81 \\
\hline SIDI $\ldots$ & 0.82 & 0.84 & 0.87 & 0.88 \\
\hline S3DI . & 0.78 & 0.75 & 0.76 & 0.88 \\
\hline SOD2 $\ldots$ & 0.81 & 0.85 & 0.83 & 0.65 \\
\hline $\mathrm{S} 1 \mathrm{D} 2$ & 0.68 & 0.80 & 0.85 & 0.82 \\
\hline S3D2 $\ldots$ & 0.80 & 0.92 & 0.84 & 0.84 \\
\hline
\end{tabular}

(1) Energy chatge $=\frac{[\mathrm{ATP}]+1 / 2[\mathrm{ADP}]}{[\mathrm{ATP}]+[\mathrm{ADP}]+[\mathrm{AMP}]}$.

(2) See table 1 for treatment codes and corresponding descriptions. 


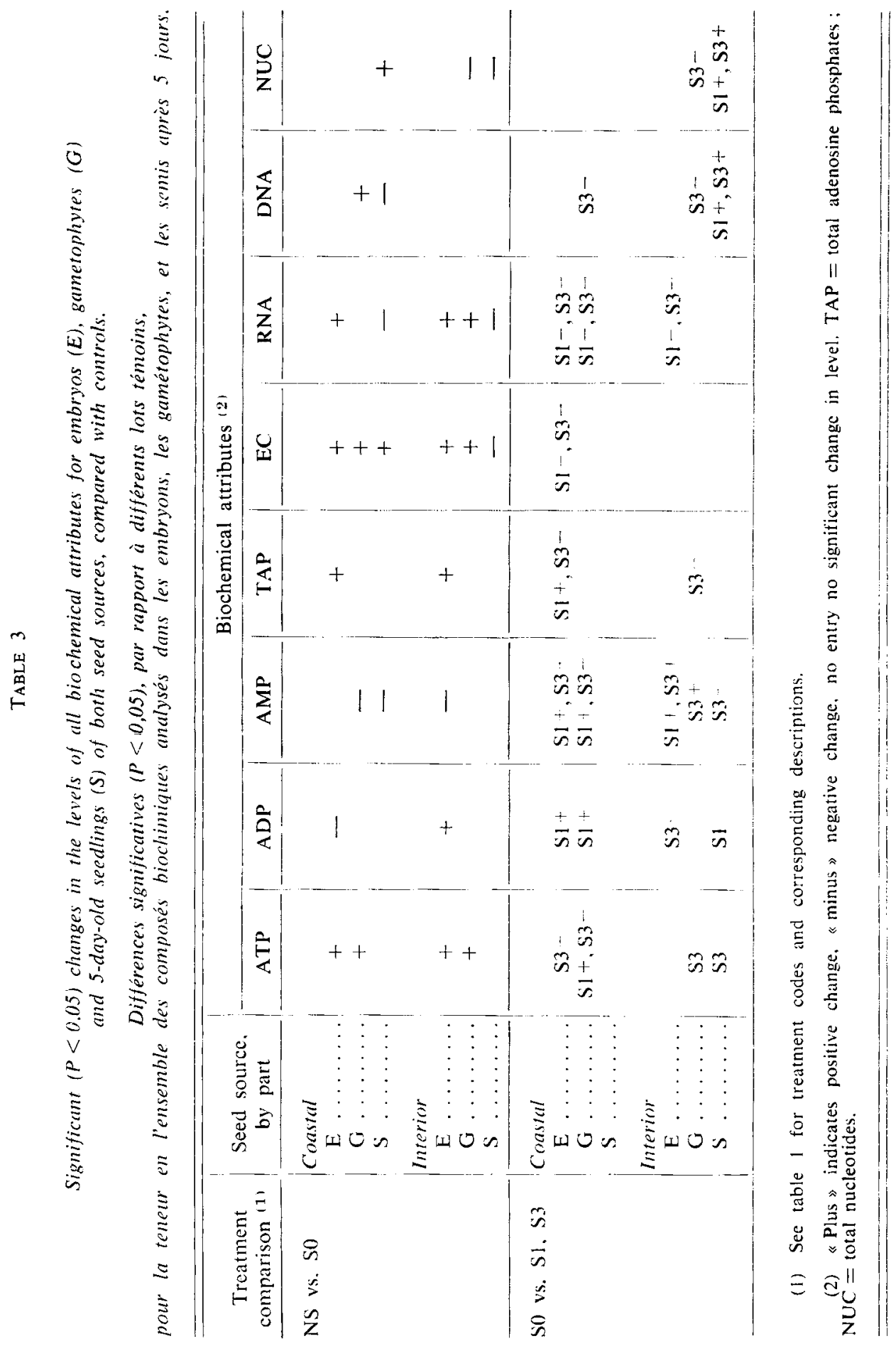




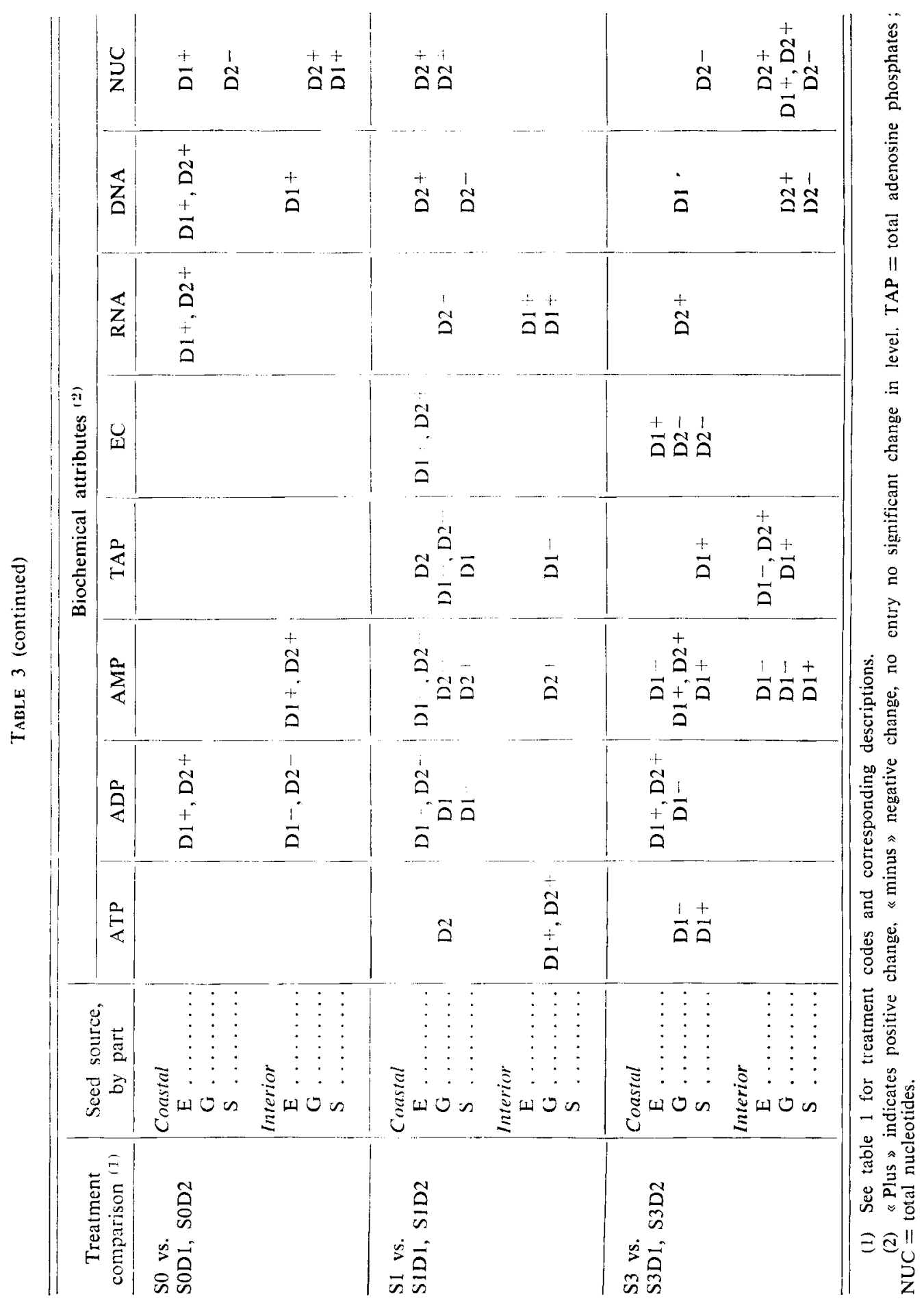




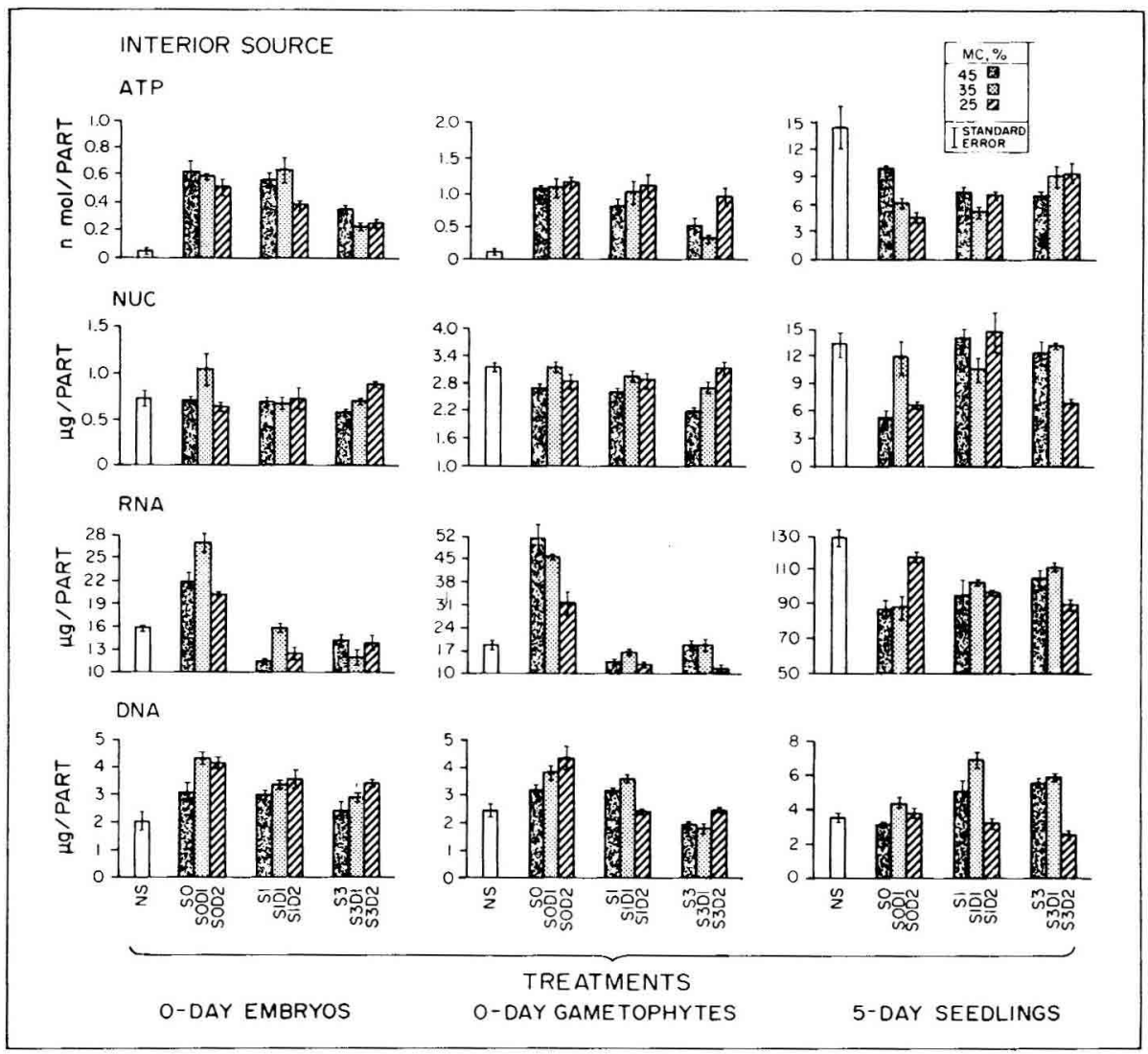

FIG. 2

Effects of redrying and storage on ATP, total nucleotides (NUC), RNA, and DNA contents in 0-day embryos and gametophytes of variously treated Douglas-fir seeds and their 5-day germinants for the interior seed source.

See table 1 for treatment-code explanations.

The figures and tables clearly show that stratification improved the energy status of seeds from both sources. ATP increased by 13 times in the embryo and by 6 times in the gametophyte (figs 1, 2). Energy charge rose to values above 0.8 (tabl. 2), which are characteristic of actively metabolizing tissues (PradeT \& RAYMOND, 1983). Similarly, Ching \& Ching (1972, 1973), Simmonds \& Dumbross (1974), SzczotKa \& TOMAZEWSKa (1981), and MURPhY \& NolaND (1982) reported markedly increased energy metabolism during stratification of ponderosa pine, Douglas-fir, sugar maple [(Acer saccharum) Marsh.], Norway maple (Acer platanoides L.), and sugar pine (Pinus lambertiana Dougl.) seeds, but AdKINS \& Ross (1984) found no positive correlation between ATP levels and dormancy status in wild oat [(Avena fatua L.) caryopses]. The increase in embryo and gametophyte ATP was accompanied by an increase in the total adenylate pool (TAP = ATP + ADP + AMP), which suggests active de novo synthesis in addition to regeneration pathways (e.g., oxidative phosphorylation, subs- 
trate-level phosphorylation) (CHING, 1982). Changes in ADP and AMP levels differed in direction between seed sources and in magnitude between embryos and gametophytes; these diverse trends may have been due both to the genetic variation between sources and to the divergent metabolic activities of embryos and gametophytes.

Stratification markedly increased RNA levels in embryos and gametophytes of both seed sources (figs 1, 2: SO vs. NS, tabl. 3). Similar results have been reported in seeds of Douglas-fir (CHING, 1966), hazel (Corylus avellana L.) (WOOD \& BRADBEer, 1967), and Norway maple (Davies \& Pinfield, 1979 ; Siater \& Bryant, 1982). However, stratification did not affect DNA and nucleotide levels in embryos (figs 1, 2), in contrast with the findings of JARVIS et al. (1968 a, b) and CHING (1966). The differences may be attributed to the variation in species and seed sources used in the respective studies or, in CHING's (1966) case, to ecotypic variations in physiological behavior (ALLEN, 1960). We noted a small increase in DNA levels and a small decrease in nucleotide levels (figs 1,2 ) in the gametophytes of both seed sources, in general agreement with CHING (1966). Thus, the supporting literature (CHINC, 1966 ; Jarvis et al., $1968 \mathrm{a}, \mathrm{b}$ : ChING \& Ching, 1972, 1973 ; Slater \& Bryant, 1982) and our findings in the companion paper (DE Matos Malavasi et al., 1985), which correlate high phosphorylative efficiency and high RNA levels with rapid seed germination, lead us to believe that the biochemical changes observed here are in fact part of the stratification effects which can alter dormant-seed metabolism to stimulate the breaking of dormancy.

Redrying stratified seeds increased RNA and DNA levels of embryos but did not affect nucleic-acid and nucleotide levels of gametophytes (SO vs. SOD1, SOD2 : tabl. 3). This disparity in response might be attributed to the fact that the gametophyte does not increase in cell number during stratification and germination, and that protein synthesis in gametophytes is largely related to mobilization of stored reserves (BEWLEY, 1982). KOEHLER (1967) showed that osmotic treatment increased respiration rate and levels of proteins and RNA in tomato seeds. More recently, SEN \& Osborne (1974) and Dell'AQuila et al. (1978) reported that hydration-dehydration treatment enhanced the ability of cereal embryos to synthesize protein, RNA, and DNA during the early hours of germination. Those findings and ours are compatible, if we assume dormancy had been broken before redrying by stratification. In our study, redrying seemed to increase the rate of both nucleic-acid synthesis and germination in parallel fashion, as shown in the companion paper (DE Matos Malavasi et al.. 1985). The correlation between producing more vigorous seedlings and higher nucleicacid content suggests that these biochemical and physiological processes may be causally related. However, more detailed studies should be conducted to explore how partially drying hydrated tissues can enhance synthesis of protein, RNA, and DNA in the early stages of seed germination.

ATP and energy charge of embryos were stable during redrying. ATP, RNA, and nucleotides may in fact have increased in parallel fashion during that process. However, this parallel increase may have been offset by parallel utilization due to rapid turnover of cell energy and a major demand for ATP in nucleic-acid and nucleotide synthesis (CHING, 1982), thereby producing the steady state we observed. Changes in ADP and AMP levels were different in magnitude and direction for the two seed sources, which may be attributed to the degradation of ADP to AMP by phosphatase in interior-source seed.

TAP levels in gametophytes varied inconsistently within and between seed sources. Generally, redrying increased ATP levels and energy charge in gametophytes 
of coastal-source seeds but did not affect ATP levels in gametophytes of the interior source and somewhat reduced their energy charge. The reduced EC, though not significant, probably indicates that ATP utilization exceeded its biosynthesis. Such differences between sources could be due to variation in the metabolic state in which seeds were arrested during development and drying, the conditions under which seeds were extracted and stored, or genetic differences. Nevertheless, TAP levels were generally preserved during redrying in embryos and gametophytes of both sources.

Storing stratified seeds of both sources for 1 and 3 months (SO vs. S1, S3 ; tabl. 3) markedly lowered RNA levels of embryos and gametophytes, indicating enhanced RNase activity during the storage period. DNA and nucleotide levels were unaffected in embryos, although they were slightly reduced in gametophytes. The companion paper (DE Matos Malavasi et al., 1985) indicates that vigor and viability of stratified seeds also were reduced throughout storage; several workers have reported that aging reduced seed vigor in cereal and dicotyledonous seeds, as expressed by RNA, DNA, and protein synthesis (CHING, $1973 \mathrm{a}, \mathrm{b}$; VAN ONCKELEN et al., 1974 ; ANDERson, 1977). Although no quantitative changes in total RNA and DNA levels were observed when viability was lost, qualitative changes were reported (CHING, 1972; OSBORNE, 1982). Therefore, the enzymatic activity triggering these qualitative changes is an important aspect in seed or seedling vigor in studies of this type.

Storing stratified seeds from both sources reduced ATP, TAP, and RNA levels and energy charge in parallel fashion. Similar parallel reductions in energy status, RNA synthetic ability, and seed vigor have been reported for barley, soybean, and crimson clover (Ching, 1973 a, b; VAN ONCKelen et al., 1974; ANDERson, 1977). Perhaps the low vigor of stored seeds may be explained by an impaired ability to synthesize, as well as to use, ATP. Storage also reduced ATP and TAP levels of gametophytes; however, energy charge was preserved, indicating that synthesis and use of energy were impaired to about the same degree. Generally, the loss of stratification benefits and subsequent deterioration throughout storage were similar for both nondried and redried stratified seeds.

None of the biochemical criteria studied in 5-day-old seedlings showed close proportionality with either the physiological or biochemical responses reported for the treated seeds. In addition, seedling data were too inconsistent for us to draw any conclusions linking seed treatments to the general metabolism of 5-day-old seedlings. The seedlings' morphological and biochemical development may have proceeded at different rates among different treatments, resulting in varied responses. Perhaps seedlings older than 5 days will more fully express stratification, redrying, and storage effects.

We conclude from these results and those of the companion paper (DE MATOS MALAVASI et $a l ., 1985$ ) that redrying may not only preserve the metabolic processes activated during stratification but may enhance them. However, these benefits are not stable after 1 or 3 months of low-temperature storage. Therefore, it would probably be best to redry stratified seeds directly before sowing to allow greatest expression of stratification benefits and promote production of the most vigorous seedlings. Investigators should next test redrying seeds before sowing on a production basis, paying special attention to seed source, maturity, and processing procedures. 


\section{Résumé \\ Stratification, séchage secondaire et stockage de graines de Douglas : conséquences biochimiques}

Certains composés biochimiques (adénosine phosphates, acides nucléiques et nucléotides totaux) ont été analysés dans les graines et les semis de Douglas [P'seudotsuga menziesii (Mirb.) Francol d'une provenance côtière et d'une provenance intérieure de l'Oregon. Il s'agissait d'étudier les interactions entre la stratification, le séchage secondaire et la conservation pour la production de semis vigoureux. Les graines ont été stratifiées avec une teneur en eau (TE) de 45 p. 100 puis séchées soit à $35 \mathrm{p} .100$ soit à $25 \mathrm{p}$. 100 et étudiées directement ou après conservation (I à 3 mois). La stratification multiplie par treize l'ATP dans l'embryon et par six dans le gamétophyte. La charge énergétique passe de 0,4 à 0,8 et l'ARN augmente de 60 à $80 \mathrm{p}$. 100 dans l'embryon et de 150 à $300 \mathrm{p} .100$ dans le gamétophytc. Un séchage secondaire des graines stratifiées jusqu’à une TE de 35 ou 25 p. 100 augmente fortement l'ARN et l'ADN dans l'embryon mais pas dans le gamétophyte. La conservation des graines re-séchées se traduit par une baisse générale de tous les composés étudiés. Les graines stratifiées re-séchées ont produit les semis les plus vigoureux, bien que celles-ci ne présentent pas d'avantage constant au niveau des composés biochimiques. Ceci peut être dû à leur métabolisme rapide. Cependant, l'effet bénéfique de la stratification et du séchage ne s'est pas maintenu chez les graines conservées des deux provenances.

Mots clés : Douglas, variabilité des semences, pouvoir germinatif, dornance, vigueur, pool d'adenylate, acides mucéliques, nucléotides, sỵnthèse des protéines.

\section{References}

Adkins S.W., Ross J.D., 1984. Adenosine triphosphate and adenylate energy charge in relation to dormancy of wild oat sceds. Can. J. Bot., 61, 3349-3354.

AL1.EN G.S., 1960. Factors affecting the viability and germination behavior of coniferous seed. IV. Stratification period and incubation temperature, Pseudotsuga menziesii (Mirb.) Franco. For. Chron., 36, 18-29.

ANDERSON J.D., 1977. Adenylate metabolism of embryonic axes from deteriorated soybean seeds. Plant P/hysiol., 59, 610-614.

A rKInSON D.E., 1969. Regulation of enzyme function. A. Rev. Microbiol., 23, 47-68.

BARNETT J.P., 1972. Drying and storing stratified loblolly pine seeds reinduces dormancy. Tree Planter's Notes, 23, 10-11.

BEWLeY J.D., 1982. Protein and nucleic acid synthesis during seed germination and early seedling growth. In : Nucleic acids and proteins in plants I., pp. 559-591, Boulter D. and Parthier B. Eds., Springer-Verlag, New York.

Ching T.M., 1966. Compositional changes of Douglas-fir seeds during germination. Plam Physiol., 41, 1313-1319.

Ching T.M., 1972. Aging stresses or physiological and biochemical activities of crimson clover (Trifolium incarnatum L. var. Dixie) seeds. Crop Sci., 12, 415-418.

Ching T.M., 1973 a. Biochemical aspects of seed vigor. Seed Sci. Technol., 1, 73-88.

Ching T.M., 1973 b. Adenosine triphosphate content and seed vigor. Plant Physiol., 51, 400-402.

Ching T.M., 1982. Adenosine triphosphate and seed vigor. In : The physiology and biochenistry of seed development, dormancy and germination, pp. 487-504, Kahn A.A. Ed., Elsevier Biomedical Press, Amsterdam.

Ching T.M., Ching K.K., 1972. Content of adenosine phosphates and adenylate energy charge in germinating ponderosa pine seeds. Plant Physiol., 50, 536-540.

Ching T.M., Ching K.K., 1973. Energy status in dormant and nondormant seeds. In : International Symposium on Dormancy in Trees. pp. 13-19, Pol. Acad. Sci.

Ching T.M., Crane J.M., Stamp D.L., 1974. Adenylate energy pool and energy charge in mature rape seeds. Plant Physiol., 54, 748-751.

Danielson H.R., Tanaka Y., 1978. Drying and storing stratified ponderosa pine and Douglas-fir seeds. For. Sci., 24, 11-16. 
Davies H.V., Pinfield N.J., 1979. RNA and protein synthesis during after-ripening of seeds of Acer platanoides. L.Z. Pflatzen Physiol., 92, 85-90.

Dell'aquila A., Savino G., De Leo P., 1978. Metabolic changes induced by hydrationdehydration treatment in wheat embryos. Pl. Cell Physiol., 19, 349-354.

De Matos Malvasi M., Stafford S.G., Lavender D.P., 1985. Stratifying, partially redrying, and storing Douglas-fir seeds : effects on growth and physiology during germination. Ann. Sci. For., 42 (4), in press.

EDwards D.G.W., 1981. A new prechilling method for true fir seeds. Proc., Intermountain Nurseryman's Association and Western Forest Nursery Association. USDA For. Serv. Gen. Tech. Rep. INT-109, Intermoutain Forest and Range Experiment Station, Ogden, UT. $148 \mathrm{p}$.

Hedderwick G.W., 1968. Prolonged drying of stratified Douglas-fir sceds affects laboratory germination. N. Z. For. Serv. Res, Leafl., 19.

Jarvis B.C., Frankland B., Cherry J.H., 1968 a. Increased DNA template and RNA polymerase associated with the breaking of seed dormancy. Plant Physiol., 43, 1734-1736.

Jarvis B.C., Frankland B., Cherry J.H., 1968 b. Increased nucleic-acid synthesis in relation to the breaking of dormancy of hazel seed by gibberellic acid. Planta, 83, 257-266.

Khan A.A., Heit E., Lippold P.C., 1968. Increase in nucleic acid synthesizing capacity during cold treatment of dormant pear embryos. Biochem. biophys. Res. Commun., 33, 391-396.

KoEHLER D.E., 1967. Studies on a treatment hastening germination of tomato seeds (Lycopersicom esculentum Mill.). M.S. thesis, Purdue University, Lafayette, IN.

Muller C., Bonnet-Masimbert M., 1983. Amélioration de la germination des faînes (Fagus sylvatica) par prétraitement en présence de polyétylène glycol. Ann. Sci. For., 40, $157-164$.

Murphy J.B., Noland T.L., 1982. Temperature effects on oxidative metabolism of dormant sugar pine secds. Plant Physiol., 70, 1410-1412.

OSBORNE D.J., 1982. Deoxyribonucleic acid integrity and repair in seed germination : the importance in viability and survival. In : The physiology and biochomistry of se'ed development, dormancy and germination, pp. 436-460, Khan A.A. Ed., Elsevier Biomedical Press, Amsterdam.

Pradet A., Raymond P., 1983. Adenine nucleotide ratios and adenylate energy charge in energy metabolism. Annu. Rev. Plant Physiol., 34, 199-224.

SFN S., Osborne D.J., 1974. Germination of rye embryos following hydration-dehydration treatment : enhancement of protein and RNA synthesis and earlier induction of DNA replication. J. exp. Bot., 25, 1010-1019.

Simmonds J.A., Dumbroff E.B., 1974. High energy charge as requirement for axis elongation in response to gibberellic acid and kinetin during stratification of Acer saccharum seeds. Plant Physiol., 53, $91-95$.

Sl.ATER R.J., BRYANT J.A., 1982. RNA metabolism during breakage of secd dormancy by low temperature treatment of fruits of Acer plantanoides (Norway maple). Anth. Bot., 50, $141-149$.

Suszka B., 1975. Cold storage of after-ripened beech (Fagus sylvatica L.) seeds. Arbor. Kónickie, 20, 299-315.

SuszkA B., Tylzowski T., 1981. Storage of acorns of the northern red oak (Quercus borealis Michx. $=Q$. rubra L.) over 1-5 winters. Arbor. Kórnickie, 26, 253-306.

Szczotka L, Tomaszicwska E., 1980. Content of ATP and acid phosphatase activity in seeds of Norway maple (Acer platanoides L.) during dormancy breaking under conditions of cold stratification. Bull. Acad. pol. Sci. Cl. II Sér. Sci. Biol., 28, 549-554.

TAO K.L., KHAN A.A., 1974. Increases in activities of aminoacyl-t-RNA synthetases during cold treatment of dormant pear embryos. Biochent. biophys. Res. Commun., 59, 764-770.

VANESSE R., 1967. Influence du séchage secondaire des graines de Pseudotsuga menziesii (Mirb.) Franco sur leur germination à $25^{\circ} \mathrm{C}$. Bull. Rech. agron. Gembloux, 2, 551-568.

VAN OnCKelen H.A., Verbeek R., KHAN A.A., 1974. Relationship of ribonucleic acid metabolism in cmbryo and aleurone to $\alpha$-amylase synthesis in barley. Plant Physiol., 53, $562-568$.

Villiers T.A., 1972. Cytological studies in dormancy. 111. Changes during low-temperature dormancy release. New Phytol., 71, 153-160.

Wood A., BradbeER J.W., 1967. Studies in seed dormancy II. The nucleic acid metabolism of the cotyledons of Corylats avellana L. seeds. New' Phytol., 66, 17-26. 